\title{
Determinant of Non-Performing Financing in Indonesian Islamic Commercial Banks in time of Covid-19 Pandemic
}

\author{
Fitria Idham Chalid \\ Magister Sains Ekonomi Islam Universitas Airlangga \\ e-mail: fitria.idham.chalid-2019@ feb.unair.ac.id \\ Firsty Izzata Bella \\ Magister Sains Ekonomi Islam Universitas Airlangga \\ e-mail: firsty.izzata.bella19@feb.unair.ac.id
}

\begin{abstract}
This study intended to determine the influence of internal and external factors of Islamic banks on the Non-Performing Financing (NPF) ratio during the global financial crisis effect Covid-19. This research by utilizing quarterly data on the panel data method with 11 Islamic Commercial Banks (IBs) in the 2019Q1-2020Q4 period sourced from financial report of each bank and the Central Statistics Agency (BPS). The results indicate that all independent variables, namely the (FDR), Bank Size, and Economic Growth have a significant negative effect on NPF, except for the (CAR). This can be inferred that the credit restructuring policy enacted by the Indonesian government has been effectively decreasing the ratio of NPF in banks, especially for IBs in Indonesia during the pandemic of Covid-19
\end{abstract}

Keywords: Bank Size, Capital Adequacy Ratio, Financing to Deposit Ratio, Gross Domestic Product, Non-Performing Financing, Covid-19

\begin{abstract}
Abstrak
Penelitian ini bertujuan untuk mengetahui pengaruh faktor internal dan faktor eksternal Bank Syariah terhadap pembiayaan bermasalah yang diukur dengan Non-Performing Fianncing (NPF) pada saat terjadinya krisis keuangan global akibat Covid-19. Penelitian ini menggunakan metode data panel dengan data kuartal pada 11 Bank Umum Syariah (BUS) pada periode 2019Q1-2020Q4 yang bersumber dari laporan masing-masing bank dan Badan Pusat Statistik (BPS). Hasil penelitian menunjukkan bahwa seluruh variabel independen yakni Financing to Deposit Ratio (FDR), Bank Size, dan Pertumbuhan Ekonomi memiliki pengaruh negatif signifikan terhadap NPF, kecuali
\end{abstract}


Capital Adequacy Ratio (CAR). Hal ini menunjukkan bahwa kebijakan restrukturasi kredit yang diberlakukan oleh pemerintah terbukti efektif dalam menekan rasio pembiayaan bermasalah di perbankan khususnya pada BUS di Indonesia terutama saat terjadinya krisis keuangan global yang disebabkan oleh pandemi Covid-19.

Kata kunci: Bank Size, Bank Size, Capital Adequacy Ratio, Financing to Deposit Ratio, Gross Domestic Product, Non-Performing Financing, Covid-19

\section{INTRODUCTION}

Banking is one of the institutions that play an essential role in the development of a country through its main function as an intermediary institution that collects funds from the public in the form of savings, cheques, deposits and distributes them back to the public in the form of credit or financing. Indonesia is one of the countries with a dual banking system that permits banks to conduct business activities with both conventional and sharia systems. Data from OJK (2020) shows that there are 14 Islamic Commercial Banks (IBs), 20 Islamic banks in the form of Sharia Business Units (UUS), and 163 Sharia Rural Banks (BPRS) in Indonesia.

In economic and banking history, financial crises hit Indonesia in recent decades such as the monetary crisis in 1998, in 2008 due to the subprime mortgage in the United States, and the financial crisis in 2020 as a result of the pandemic of Coronavirus Disease-2019 (Covid-19). The impact of the crisis hit banking stability, and often resulted in the collapse. In 1998, the monetary crisis resulted in many banks being liquidated, stopped, and merged with other banks to survive. 10 years later, the 2008 monetary crisis gave an impact on a high NPF ratio of around 4.97\%. A high NPF level indicates a deteriorating health condition of the bank due to many financing problems in bank operational activities (Aryani, 2016).

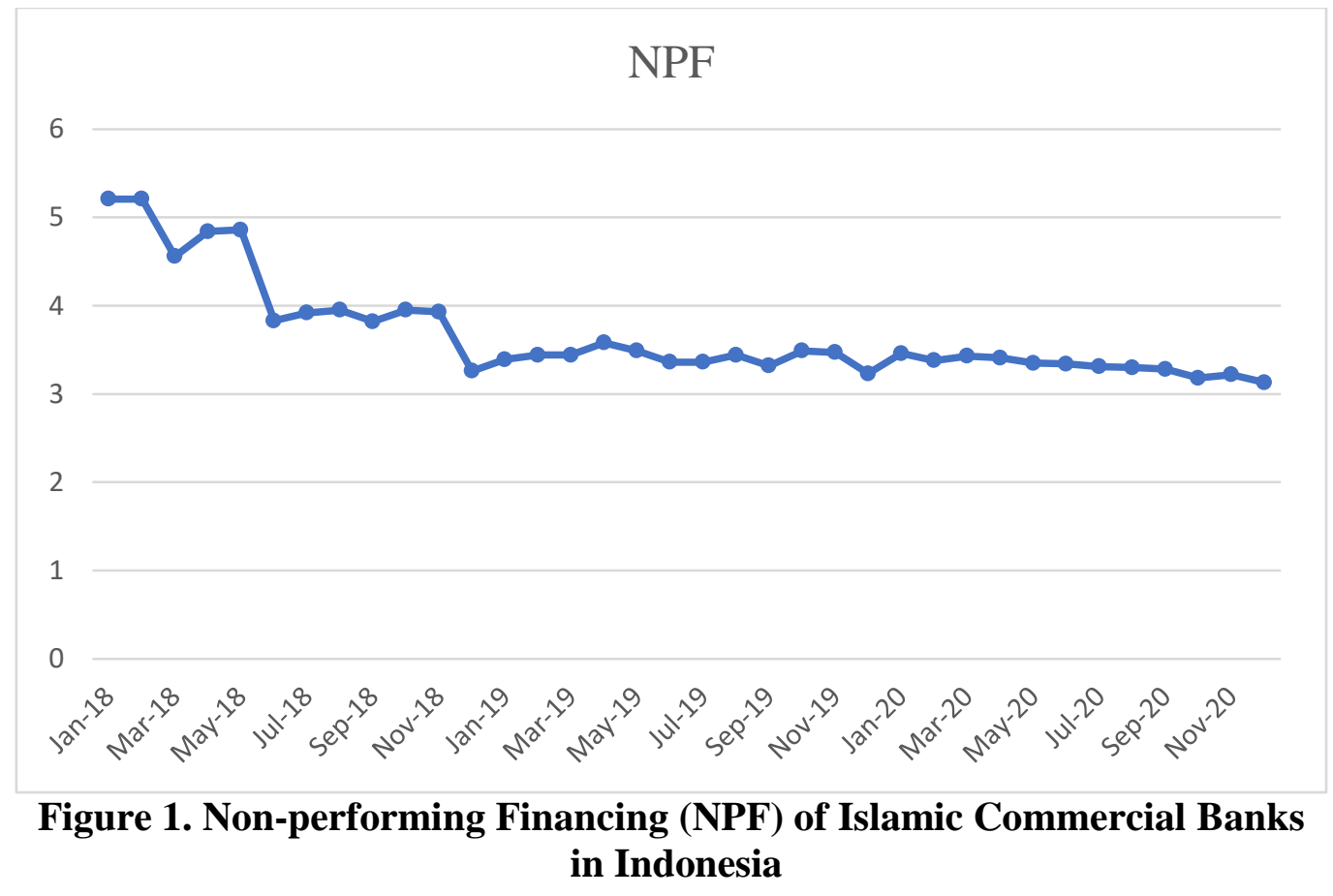

Source: Islamic Banking Statistics 2018-2020 
On the other hand, the financial crisis in 2020 as a result of Covid-19 seems to be well-handled by the government, especially for IBs in Indonesia. This can be seen in Figure 1 where the level of NPF in 2018 to 2020 tends to decline and stagnate at $3.20 \%$ far below the 2008 financial crisis which had a high NPF ratio above $4.0 \%$. Various policies are taken by the government, such as credit restructuring, are seen effectively suppresses the increase in NPF. When compared to the monetary crisis in previous years, the financial crisis in 2020 had a lower non-performing financing ratio. Thus, this difference is an interesting thing to study to implement better policies if some crisis probably happened in the future which can disrupt banking stability in Indonesia.

Various studies on the factors that affect NPF in Islamic banks have been studied previously, on the FDR variable, Ferhi (2018) and Munifatussa'idah (2020) agree that FDR has a significant negative effect on NPF. Meanwhile, research by Effendi, Thiarany, and Nursyamsiah (2017), İncekara and Çetinkaya (2019) showed contradictory results on the direction of the significant influence between CAR and NPF. As for the Bank Size variable, the results of research by Aryani (2016) Aand Syamlan and Jannah (2019) show that Bank Size has a significant negative effect on NPF, in contrast to Misman et al. (2015) who stated in their research that Bank Size had no effect significant to the NPF. Not only in the Bank Size variable but also the inconsistency of results was also found in the relationship between GDP and NPF variables where İncekara and Çetinkaya (2019) concluded that there was a significant negative coefficient direction, research by Effendi et al. (2017) showed a positive coefficient relationship, meanwhile, Aryani (2016) shows that there is no influence between the two variables.

According to the problems and inconsistencies of the research results above, the researchers argue that further research is required on studying the determinants of NonPerforming Finance (NPF) in Islamic banks in Indonesia, especially during the global financial crisis. The reason is that this research can be useful for policymakers such as Bank Indonesia, OJK, and banking practitioners in Indonesia as a reference in making policies for mitigating and controlling credit risk or NPF during a crisis. Therefore, this study will examine how bank internal factors and bank external factors can affect nonperforming financing, especially for Islamic Commercial Banks in Indonesia.

\section{LITERATURE REVIEW}

\section{Non-Performing Financing (NPF)}

Non-performing Financing (NPF) is the ratio to assessing the quality of a bank's performance, meanwhile, it also shows an indication of the existence of problems in the bank which if not addressed immediately will endanger the bank. NPF is a condition of customers who can not pay their loan to the bank partially or completely according to the agreement (Simanjuntak, 2016). The NPF problem is not an odd thing in the banking world, even with the application of the right principles to channel funds to the public or customers, this problem can still occur.

NPF is a basic financial ratio that can provide assessment information on the condition of capital, profitability, credit risk, market risk, and liquidation. Generally, the NPF ratio is applied as a short-term target in the banking industry, where the higher the NPF ratio indicates the lower the level of bank liquidity to Third-Party Funds (DPK). This is because most of the funds disbursed by banks in the form of financing are in the form of deposits from DPK. Several factors that cause NPF can be classified into three 
groups, namely internal bank factors, debtor factors, and external bank and debtor factors (Simanjuntak, 2016).

Bank internal factors are indicators that come from the bank itself. Massive credit expansion activities without standardization of prospective debtor analysis and inadequate supervision by banks, the number of financing that exceeds the bank's ability to liquidate, and the weak ability of banks to detect the possibility of NPF are some of the major factors causing the increase in the NPF ratio. In terms of debtor internal factors, several factors cause the occurrence of banking NPF, namely the good or bad character of the debtor, the decline of the debtor's business, miss management, and the age factor. Furthermore, the formula for calculating NPF is as follows:

$$
\mathrm{NPF}=\frac{\text { Non }- \text { Performing Financing }}{\text { Financing }} \times 100 \%
$$

\section{Factors Affecting Non-Performing Financing Financing to Deposit Ratio (FDR)}

The level of financing is reflected in the Financing to Deposit Ratio (FDR) as a comparison ratio between the number of funds disbursed in the form of financing and the number of public funds and bank-owned capital used. Controlling the FDR ratio is still a dilemma for the banking world. According to Solihatun (2014), a high FDR ratio indicates that the Bank has maximized its function as an intermediary, namely a condition when the ability to channel funds is higher than raising funds, but this situation means reducing the level of bank liquidity and increasing the risk of nonperforming financing. Conversely, when the FDR is low, the bank's liquidity position is in good condition, while, it also means that the bank is not capable to channel financing optimally which will ultimately reduce profitability. Specifically, FDR can be formulated as follows:

\section{Capital Adequacy Ratio (CAR)}

$$
\text { FDR }=\frac{\text { Total of Financing }}{\text { Third Party Fund }} \times 100 \%
$$

The Capital Adequacy Ratio (CAR) can be defined as the ratio between the net capital owned by the bank and its total assets. In general, it is aimed to accommodate the risk of loss that may be faced by the bank. The higher the CAR, the better the bank's ability to bear the risk of any risky credit /productive assets (Simanjuntak, 2016). If the CAR value is high, the bank can finance operational activities and make a sizeable contribution to profitability. CAR can be measured by comparing capital with ATMR from the point of view of protecting the interests of depositors, the comparison between capital and liabilities is an indication of the level of security of public deposits in banks. The calculation is the ratio of capital associated with third-party deposits (current accounts, giro, and savings). The formula for calculating CAR is as follows:

\section{Bank Size}

$$
\mathrm{CAR}=\frac{\text { Capital }}{\mathrm{ATMR}} \times 100 \%
$$

The size of a bank can be measured by the total assets owned (Incekara \& Çetinkaya, 2019). Total assets are one of the indicators that show the development of Islamic banking. Assets owned by commercial banks can be categorized into several groups including assets in cash, investments in sharia securities, financing provided, investment in fixed assets. If the assets owned by Islamic banks have increased, it will show that there is a fairly rapid growth in Islamic banking in Indonesia. However, if the 
total assets owned by Islamic banks are small, it will affect the level of economies of scale as one of the positioning map strategies in a business competition (Haryono, 2004).

\section{Economic growth}

Gross Domestic Product (GDP) is one indicator of economic growth. It is the value of goods and services in a country produced by production factors belonging to citizens and foreign countries (Sukirno, 2013). GDP at current prices can be used to see the shift and structure of the economy, while constant prices are used to determine economic growth from year to year. National income at current prices is the value of goods and services produced by a country in one year and is valued at the prices prevailing in that year. While the fixed price is the price that applies in a certain year which is then used to assess the goods and services produced in other years. According to Mankiw (2007), the purpose of GDP is to summarize economic activity in a certain value of money during a certain period.

There are two ways to look at GDP figures, one is to look at GDP as the total income of everyone in the economy, and the other is to look at the total expenditure on the economy's output of goods and services. From both points of view, it is clear why GDP is a reflection of economic performance. Similarly, an economy with a large output of goods and services can best meet the demands of households, firms, and governments (Mankiw, 2007).

\section{Relationship Between Variables}

\section{Effect of Financing to Deposit Ratio (FDR) on NPF}

If the FDR is high, the NPF will increase because the high FDR number means that more funds are disbursed in the form of financing so the risk of credit or nonperforming financing borne by the Bank will also be high. This is in line with the results of Aryani (2016) which shows that FDR has a significant positive effect on NPF. Then the hypothesis taken in this study are:

H1: FDR has a significant positive effect on NPF

\section{Effect of Capital Adequacy Ratio (CAR) on NPF}

If the CAR is high, the NPF ratio will be low, because the higher the CAR owned by a bank, the greater the number of capitals used to accommodate the risk of default losses. A high NPF will erode the capital owned by the bank, therefore CAR is an important factor in mitigating the risk carried out by banks related to the possibility of defaulting debtors in paying their loans. This is in line with the results of research from Syamlan and Jannah (2019) which shows that CAR has a significant negative effect on NPF. Based on the above, the hypotheses taken in this study are:

$\mathrm{H} 2$ : CAR has a significant negative effect on NPF

\section{Effect of Bank Size on NPF}

The larger the asset or size of a bank, the lower the NPF risk borne. Because the higher the assets of a bank, the greater the number of funds disbursed into financing, so that banks will be more careful and selective in choosing customers who want to apply for financing and this will certainly reduce the risk of non-performing financing faced by banks. This is in line with the research of Misman et al. (2015) which shows that bank size has a significant negative effect on NPF. From the explanation above, thus, the hypotheses taken in this study are: 
H3: Bank Size has a significant negative effect on NPF

\section{Effect of Economic Growth on NPF}

GDP is an indicator of economic growth. When economic growth increases, the risk of non-performing financing (NPF) will be low. Because when a country's economic growth increases, economic activity or activities will run well so that it will reduce non-performing financing to creditors. This is in line with the research of Incekara and Çetinkaya (2019) which states that GDP has a significant negative effect on NPF. Based on the above, the hypotheses taken in this study are:

H4: Economic Growth has a significant negative effect on NPF

\section{METHOD}

This study applied a quantitative approach with a balanced panel regression model using secondary data on a quarterly scale in the 2018Q1 to 2020Q4 period sourced from the quarterly reports of each Islamic Commercial Bank on the bank's official website or uploaded on the OJK website (www.ojk.go.id). The panel data model was chosen because it can explain changes at the banking level which time series and cross-section models cannot individually (Misman et al., 2015). Additionally, Gujarati (2004) also emphasizes that the panel data model aims to provide data that is more informative, more varied, minimal collinearity between variables, and greater degrees of freedom, and is more efficient because panel data is a combination of cross-sectional and crosssectional observations time-series.

\section{Sample Procedure}

Sampling in this study is taken using a purposive sampling technique, namely the technique of determining the sample with certain considerations from the researcher (Sugiyono, 2018). Of the total 14 IBs in Indonesia, 11 of them were taken as research samples with the consideration that they have published financial reports for the 4th quarter of 2020. The number of observations used in the study was 132 data.

\section{Analysis Technique}

The data analysis technique utilized is panel data regression with the Random Effect Model (REM) which can also be called the Generalized Least Square (GLS) technique. GLS is a procedure by transforming variables to meet the classical assumptions so that the estimator can be declared BLUE (Gujarati, 2004, p.386). The variables used in this study are Non-Performing Financing (NPF) as endogenous variables, while exogenous variables consist of Financing to Deposit Ratio (FDR), Capital Adequacy Ratio (CAR), Bank Size with total assets as an indicator, and Economic Growth with GDP as a proxy. Due to the difference in units between the variables studied, the Asset variable has been transformed into the natural logarithm (ln).

Hence, the specifications of the linear-log model in mathematical form in this study are:

$$
N P F_{i t}=\beta_{0}+\beta_{1} F D R_{i t}+\beta_{2} C A R_{i t}+\beta_{3} \ln (A S S E T)_{i t}+\beta_{4} G D P_{i t}+\omega_{i t}
$$

The sub-index in the model explains $i$ as horizontal cross-section data, namely banks, and $t$ describes the time which in this study uses quarterly data. The coefficient represents a constant coefficient for data variation, while the finite coefficient shows the slope of the coefficient for the independent variable while explaining the error 


\section{RESULT AND DISCUSSION \\ Descriptive statistics}

Table 1 depicted a summary of the descriptive statistics between the independent variables and the dependent variable used in this study consisting of the mean, median, standard deviation, and minimum and maximum values to explain the data criteria. On average, the NPF ratio of 11 IBs in Indonesia in the 2018 to 2020 period is fairly high because it is at $6.9 \%$. However, this phenomenon is accompanied by the average FDR and CAR ratios which are at $84 \%$ and $22 \%$, respectively. The CAR value shows a much higher figure when compared to Basel's requirement of only $8 \%$.

Tabel 1. Descriptive Statistics

\begin{tabular}{llllllll}
\hline Variable & Obs & Unit & Mean & Median & Std Dev & Min & Max \\
\hline NPF & 132 & $\%$ & 6.929470 & 3.305 & 19.4235 & 0.01 & 161.1 \\
FDR & 132 & $\%$ & 84.121820 & 86.915 & 21.64914 & 4.24 & 196.73 \\
CAR & 132 & $\%$ & 22.784850 & 19.815 & 7.973695 & 14.45 & 49.44 \\
LNASSET & 132 & Nominal & 16.464470 & 16.19 & 1.074812 & 14.5 & 18.66 \\
GDP & 132 & $\%$ & 3.197500 & 5.05 & 2.952677 & -2.07 & 5.17 \\
\hline
\end{tabular}

Source: Processed data

Estimated Model

Table 2. Estimated Model Result

\begin{tabular}{lll}
\hline Test & P-value I alpha & \multicolumn{1}{c}{ Decision } \\
\hline Chow Test & $0.0000<0.05$ & Reject H0, select FEM \\
Hausman Test & $1.0000>0.05$ & Accept H0, select REM \\
Langrange Test & $0.0000<0.05$ & Reject H0, select REM \\
\hline
\end{tabular}

Source: Processed data

The results of the Chow test indicated that the probability value is smaller than the 5\% significance level, therefore, the best model according to this test is the Fixed Effect Model (FEM). The next test is to apply the Hausman test which intended to choose between the FEM model and the Random Effect Model (REM), according to the test results it was found that the p-value is greater than 5\% alpha, then the REM model was selected. From the two tests above which show different results, the model selection is continued to the Breusch-Pagan Random Effect Langrage Multiplier Test, the probability value indicates that the REM model is better than the other 2 models, hence, REM was chosen for the classical assumption and regression test stages of panel data.

\section{Classical Assumption test}

The first classical assumption test stage is the Jarque-Bera normality test. Hypothesis 0 states that the residuals are normally distributed. By comparing the Jarque-Bera probability value to the $5 \%$ alpha value, which is $0.0000<0.05$, it is concluded that rejecting $\mathrm{H} 0$ means that the residuals are not normally distributed. However, Gujarati (2004) argues that the t-test and F-test procedures are still valid when the research sample is large, which in this study has a sample of 132. The next stage is the Multicollinearity Test using the Pairwise Correlation Matrix test which shows that all values in each variable are smaller than 0.8 , meaning that there is no multicollinearity in the variables used. 
The heteroscedasticity test is carried out by comparing the value of Sum Square Resid in Weight Statistics $(9777,190)$ which is smaller than Sum Square Resid Unweight Statistics (12980.17), it can be concluded that there is heteroscedasticity. However, because the selected model is the REM or GLS technique, the heteroscedasticity problem can be overcome since the variance used has been transformed into homoscedasticity, therefore, it is declared capable of producing a BLUE estimator.

The last stage is the Autocorrelation Test seen from the calculated Durbin Watson (DW) value which is taken from the output of 0.731901 and compared with the DW value table with details of DL of 1.6539 , and DU of 1.7786 . By calculating these numbers, it can be concluded that rejecting $\mathrm{H} 0$ means that there is autocorrelation. According to Gujarati (2004), individual error components with each other on the assumption of Error Correction Model (ECM) or REM are not correlated between cross-section units and time series, meaning that in this model there is no autocorrelation between errors. He further explained that in ECM, intercepts represent the average value of all intercepts (cross-section) and components represent (random) deviations of individual intercepts from the average value.

\section{REM Regression Analysis}

Regarding the test in selecting the best model, it is concluded that the effect of the independent variable on the NPF will be explained through the REM regression results.

Tabel 3. Hasil Analisis Regresi REM

\begin{tabular}{|c|c|c|c|c|c|}
\hline Variable & Coef & Std Error & t-statistics & Probability & $\begin{array}{l}\text { Hypothesis } \\
\text { Testing }\end{array}$ \\
\hline FDR & -0.622185 & 0.045562 & -13.655880 & $0.0000 * *$ & Rejected \\
\hline CAR & -0.221669 & 0.213827 & -1.036674 & 0.3019 & Rejected \\
\hline LNASSET & -10.20879 & 3.186493 & -3.203771 & $0.0017 * *$ & Accepted \\
\hline GDP & -0.887649 & 0.315003 & -2.817909 & $0.0056^{* *}$ & Accepted \\
\hline $\mathbf{C}$ & 235.2401 & 53.68449 & 4.381900 & 0.0000 & \\
\hline \multicolumn{2}{|c|}{ R-squared } & & \multicolumn{2}{|c|}{0.580177} & \\
\hline \multicolumn{2}{|c|}{ Adj R-squared } & & \multicolumn{2}{|c|}{0.566954} & \\
\hline \multicolumn{2}{|c|}{ F-statistic } & & \multicolumn{2}{|c|}{43.87706} & \\
\hline \multicolumn{2}{|c|}{$\operatorname{Prob}($ F-statistic) } & & \multicolumn{2}{|c|}{0.0000} & \\
\hline
\end{tabular}

Source: Processed Data

According to table 3, it is written that the value of Adj R-squared reaches 0.566954 , which means the model can explain the strong influence of the independent variable on the NPF variable, which is $56.69 \%$, while the remaining $43.31 \%$ is explained by other variables outside the model. Simultaneously by comparing the probability $\mathrm{F}$ statistic and the critical value (5\%), it was found that p-value $0.0000<$ 0.05, meaning that simultaneously all independent variables, namely FDR, CAR, ASSET, and GDP together have a significant effect on NPF. Meanwhile, by seeing partially through the t-test, it is undeniable that 3 of the 4 independent variables, namely FDR, ASSET, and GDP, have a significant effect, all of which have a negative coefficient direction. 


\section{Financing to Deposit Ratio (FDR) to Non-Performing Financing (NPF)}

The results of the study through the t-test with the Random Effect Model (REM) indicated that FDR had a significant negative effect on NPF. This can be seen from the probability value of 0.0000 which is smaller than the critical value (alpha) of $5 \%$. Judging from the coefficient value, it is found that an increase of $1 \%$ in FDR will have an impact on a decrease in NPF of $62.21 \%$ with the assumption that other variables are cateris paribus. Hence, it can be concluded that $\mathrm{H} 1$ is rejected means that there is a significant negative relationship between FDR and NPF, the results of the study show differences with the proposed 1st hypothesis. With an average FDR of $84.12 \%$ in 11 IBs samples categorized as healthy banks according to BI, it can be interpreted that the number of funds in Islamic banks has been used optimally in financing distribution.

This shows that the more financing disbursed by Islamic banking, the level of non-performing financing will be responded to by a decrease in NPF, meaning that the risk of financing that will be borne will be less. In contrast, the negative influence between FDR and NPF which contradicts the proposed hypothesis is supported by a policy issued by the government, namely POJK No. 11 of 2020, one of which contains financing/credit restructuring in conventional and Islamic banking. This policy has an impact on NPF which can be suppressed even though the financing disbursed increases. Thus, hypothesis 1 which states that FDR has a significant positive effect on NPF in this study is rejected.

The results of this study are in line with Akbar (2016), Wulandari and Utami (2019), and Munifatussa'idah (2020) which mentioned that Islamic banking tends to be more careful in distributing financing by reducing the nominal number of financing in low-risk sectors, one of which is consumer sector.

\section{Capital Adequacy Ratio (CAR) to NPF}

Through partial testing, it was found that CAR had no significant effect on NPF.

The $1 \%$ increase in CAR resulted in a decrease in NPF by $22.16 \%$, meaning that the greater the CAR, the greater the capital used by the BUS to accommodate the risk of default losses. The results of this study are not suitable to the expected hypothesis 2 , so it can be concluded that rejecting H2, CAR has no significant effect on NPF. CAR has an important role, namely in maintaining risk management practices in Islamic banking, because by maintaining a high CAR ratio, Islamic banking will be helped in terms of expertise and discipline in managing risk exposure (Misman et al., 2015). The results of this study are supported by Nihayah et al (2018) by having a good level of liquidity, the possibility of financing risks faced by banks will be submerged. If viewed from the direction of the negative coefficient between CAR and NPF, this is in line with the research of Aryani (2016) which was conducted on 11 BUS in the 2010-2014 period. He explained that the higher the CAR, the greater the number of capitals used to accommodate the risk of default losses

However, in this research sample, CAR does not have a significant effect, this shows that the fulfillment of minimum capital by BUS in the 2018-2020 period has not yet reached the standard level. The CAR that should be used to pay non-performing loans on the NPF becomes insignificant because of the presence of the Deposit Insurance Corporation (LPS) which can be used by banks to meet liquidity needs. On the other hand, banks do not need to bear losses due to high NPF by taking the proportion of CAR because financing problems during the research period, especially in 2020 can be restructured according to POJK No. 11 of 2020. Thus, it can be concluded that hypothesis 2 which states that CAR significant negative effect on NPF is rejected. 


\section{Bank Size to NPF}

Based on the t-test, it was found that the probability of Total Assets (LNASSET) as a proxy for Bank Size of 0.0017 is smaller than the 5\% real level with a coefficient that indicates a negative direction, meaning that there is a significant negative effect between Total Assets and NPF. So, Hypothesis 3 which states that Bank Size has a significant negative effect on NPF is accepted. An increase of $1 \%$ in Assets will have an impact on a decrease in NPF of $1020 \%$. The number of assets owned will affect the performance of banks that are more selective in choosing the financing to be distributed, so that the risk of default will be reduced so that it will have an impact on a low NPF ratio.

The results of this study are in line with studies conducted by Misra and Dhal (2012), Aryani (2016), Damanhur et al. (2018), Chamberlain, Hidayat, and Khokhar 2020) which state that there is a significant negative relationship between Total Assets and NPF/NPL. He explained that banks with large assets will have a great opportunity to increase the level of risk they will bear so that they have a better ability to deal with non-performing financing.

\section{Economic Growth against NPF}

Economic growth in this study using the GDP growth rate based on constant prices (year on year) to measure economic activity in the aggregate. The GDP growth rate is the most common proxy and can directly measure macroeconomic development (Haryono et al, 2016). In this study, it is known that GDP has a significant negative effect on NPF where a $1 \%$ increase in GDP will reduce NPF by $88.7 \%$. The results of this study lead to hypothesis 4 which states that Economic Growth has a significant negative effect on NPF to be accepted. The strengthening of GDP indicates that the productivity of goods and services increases, so that the potential for non-performing financing will decrease, which means that the NPF ratio will decrease and ultimately the profitability of Islamic banking will increase.

The results of this study are in line with the research of Haryono (2004) and Damanhur et al. (2018) who examined Islamic banking in Indonesia, as well as İncekara and Çetinkaya (2019) in Turkey, which showed that GDP is an important factor that has a significant negative effect on NPF. Therefore, maintaining the stability and growth of the country's economy is one way to reduce the number of problematic financing in the banking sector.

\section{CONCLUSION}

Non-Performing Financing (NPF) is an indicator in assessing the performance of bank functions. The higher the NPF ratio, the lower the level of bank liquidity to ThirdParty Funds (DPK). Therefore, every bank must be able to maintain the NPF ratio. Based on the results of data analysis and discussion in this study simultaneously all variables Financing to Deposit Ratio (FDR), Capital Adequacy Ratio (CAR), Bank size, and Economic Growth have a significant effect on Non-Performing Financing (NPF). As for partially, FDR, ASSET, and GDP have a significant negative effect on NPF, on the other hand, CAR does not have a significant effect on NPF.

The results of this study can be considered for policymakers such as Bank Indonesia, OJK, and banking practitioners in Indonesia to take policies to mitigate and control credit risk or non-performing financing, especially during the global financial crisis so that banks in Indonesia are stronger and ready when hit by a financial crisis. global. For instance, some regulators can make a policy to lower BI7DRR so banks can 
still provide a financing with a competitive margin rate while they not obliged to give the high return for investor or depositors. Besides, in terms of theoretical implication, this result of study can be beneficial to enrich literature regarding Islamic banks, credit risk, and liquidity risk.

However, several limitations can be considered for future research, namely, there is still the possibility that there are other internal and external bank variables that can affect the NPF outside of this study. Therefore, further research can add several variables such as Operational Costs, Inflation, Interest Rates, and other variables, or can compare the effect of NPF on Islamic banks and conventional banks during the global financial crisis so that the performance between these two banking systems can be assessed.

\section{REFERENCES}

Akbar, D. A. (2016). Inflasi, Gross Domesctic Product (Gdp), Capital Adequacy Ratio (Car), Dan Finance To Deposit Ratio (Fdr) Terhadap Non Performing Financing (Npf) Pada Bank Umum Syariah Di Indonesia. I-Economics, 2(2), 19-37.

Aryani, et al. (2016). Faktor-Faktor yang Memengaruhi Non Performing Financing pada Bank Umum Syariah Indonesia Periode 2010-2014. Jurnal Al-Muzara'ah, 4(1), 44-60.

Chamberlain, T., Hidayat, S., \& Khokhar, A. R. (2020). Credit risk in Islamic banking: evidence from the GCC. Journal of Islamic Accounting and Business Research, 11(5), 1055-1081. https://doi.org/10.1108/JIABR-09-2017-0133

Damanhur, Damanhur; Albra, Wahyuddin; Syamni, Ghazali; Habibie, M. (2017). What is the Determinant of Non-Performing Financing in Branch Sharia Regional Bank in Indonesia. Emerald Reach Proceedings Series, 1, 265-271. https://doi.org/10.1108/978-1-78756-793-1-00081

Effendi, J., Thiarany, U., \& Nursyamsiah, T. (2017). Factors Influencing NonPerforming Financing (NPF) at Sharia Banking. Walisongo: Jurnal Penelitian Sosial Keagamaan, 25(1), 109. https://doi.org/10.21580/ws.25.1.1540

Ferhi, A. (2018). Credit risk and banking stability: a comparative study between Islamic and conventional banks. International Journal of Law and Management, 60(4), 1009-1019. https://doi.org/10.1108/IJLMA-05-2017-0112

Gujarati, D. N. (2004). Basic Econometrics. Tata McGraw-Hill Education.

Haryono. (2004). Ekonomi Keuangan dan Bank. Raja Grafindo Persada.

İncekara, A., \& Çetinkaya, H. (2019). Credit Risk Management: A Panel Data Analysis on the Islamic Banks in Turkey. Procedia Computer Science, 158, 947-954. https://doi.org/10.1016/j.procs.2019.09.135

Mankiw, N. G. (2007). Makroekonomi (Edisi Keen). Erlangga.

Misman, F. N., Bhatti, I., Lou, W., Samsudin, S., \& Rahman, N. H. A. (2015). Islamic Banks Credit Risk: A Panel Study. Procedia Economics and Finance, 31(15), 7582. https://doi.org/10.1016/s2212-5671(15)01133-8

Misra, B., \& Dhal, S. (2012). Pro-cyclical Management of Banks ' NonPerforming Loans by the Indian Public Sector Banks Pro-cyclical Management of Banks ' Non -Performing Loans by the Indian Public Sector Banks. RBI Occasional Papers, March, 1-23.

Munifatussa'idah, A. (2020). Determinants Non-Performing Financing (NPF) in 
Indonesia Islamic Banks. EQUILIBRIUM: Jurnal Ekonomi Syariah, 8(2), 255274. https://doi.org/10.21043/equilibrium.v8i2.7874

Nihayah, Ana Zahrotun; Walyoto, S. (2018). Identification of Non Performing Financing Alteration Measured by Microeconomic Variable Sharia Banking. Journal of Finance and Islamic Banking, 1(1), 23-38. https://doi.org/10.22515/jfib.v1i1.1245

OJK. (2020). SPS Perbankan Syariah 2020. Journal of Chemical Information and Modeling.

Simanjuntak, J. (2016). Pengaruh Capital Adequacy Ratio (CAR), Loan to Deposit Ratio (LDR), dan Non Performing Loan (NPL) Terhadap Return on Assets (ROA) Pada Sektor Perbankan di Bursa Efek Indonesia. Jurnal Bisnis \& Manajemenurnal Bisnis \& Manajemen, 2(2), 102-111.

Solihatun, . (2014). Analisis Non Performing Financing (Npf) Bank Umum Syariah Di Indonesia Tahun 2007 - 2012. Jurnal Ekonomi Pembangunan, 12(1), 58. https://doi.org/10.22219/jep.v12i1.3655

Sugiyono. (2018). Metode Penelitian Bisnis. Alfabeta.

Sukirno, S. (2013). Makro Ekonomi, Teori Pengantar (Edisi Keti). PT. Raja Grafindo Persada.

Syamlan, Y. T., \& Jannah, W. (2019). the Determinant of Credit Risk in Indonesian Islamic Commercial Banks. Share: Jurnal Ekonomi Dan Keuangan Islam, 8(2), 181-206. https://doi.org/10.22373/share.v8i2.5051

Wulandari, M. S; Aprilliani Utami, S. (2019). Determinant of Non-performing Financing in Indonesia Islamic Bank. KnE Social Sciences, 3(13), 453. https://doi.org/https://doi.org/10.18502/kss.v3i13.4223. 